\title{
HUBUNGAN PEMERINTAHAN DAERAH DALAM MENGELOLA PENDAPATAN ASLI DAERAH (PAD) BERDASARKAN UNDANG- UNDANG 23 TAHUN 2014
}

\author{
Muhammad Kamal \\ Dosen Fakultas Ilmu Hukum, Universitas Muslim Indonesia, Makassar \\ *Email Corresponding Author: muhkamal.hidjaz@umi.ac.id
}

Received: 15 September 2019

Accepted: 10 Oktober 2019

\begin{abstract}
Abstrak. Penelitian ini bertujuan untuk mengkaji hubungan antara DPRD dengan Kepala Daerah dalam mengelola sumbersumber Pendapatan Asli Daerah (PAD) berdasarkan UU No. 23 Tahun 2014 Tentang Pemerintahan Daerah (UU Pemerintahan Daerah). Penelitian ini menggunakan metode penelitian hukum normatif yang biasa pula disebut dengan penelitian hukum doktrinal. Adapun kesimpulan dari penelitian ini ialah: 1) Kepala Daerah harus melakukan pengelolaan keuangan daerah dengan baik sebagai konsekwensi dari Otonomi Daerah;2) PAD merupakan salah satu faktor yang paling penting dalam meningkatkan kapasitas fiskal daerah; dan 3) Hubungan antara DPRD dengan Kepala Daerah merupakan kemutlakan dalam menghadirkan kebijakan daerah yang berdampak pada peningkatan PAD.
\end{abstract}

Kata Kunci:

UU Pemerintahan Daerah; Pendapatan Asli Daerah;

Kepala Daerah; DPRD.

\section{PENDAHULUAN}

\section{A. Latar Belakang}

Esensi Pemerintahan Daerah ialah berhubungan dengan kewenangan yang melekat pada Kepala Daerah dan Dewan Perwakilan Rakyat Daerah dalam mengurus dan mengatur daerahnya. Kewenangan Pemerintahan Daerah berkaitan dengan pembagian kekuasaan dalam menjalankan roda pemerintahan dan terkooptasi pada sistem pemerintahan negara federal atau negara kesatuan. ${ }^{1}$

Hakikat negara kesatuan memiliki dua sifat utama, yaitu sistem pemerintahan yang bersifat sentralistik/dekonsentrasi dan desentralistik. Kedua sifat ini menghadirkan mekanisme pemerintahan dalam hubungannya antara Pemerintah Pusat dengan Pemerintah Daerah, dan berkaitan dengan bentuk, susunan, pembagian kekuasaan yang ada pada negara. ${ }^{2}$

\footnotetext{
${ }^{1}$ Jalil, Husni, La Ode Husen, Andi Abidin, and Farah Syah Rezah. Hukum Pemerintahan Daerah Dalam Perspektif Otonomi Khusus. Makassar: CV. Social Politic Genius (SIGn), 2017, hlm. 7.

${ }^{2}$ Kranenburg, Roelof. Algemene Staatsleer. Haarlem: H.D. Tjeenk Willink, 1949, hlm. 5 - 7.
} 
Implementasi sistem Pemerintahan Daerah di Indonesia dimana perihal kewenangan, khususnya desentralisasi, penyelenggaraan pemerintahan dan penyelenggaraan keuangan daerah telah diatur dalam Undang-Undang Nomor 23 Tahun 2014 tentang Pemerintahan Daerah (UU Pemerintahan Daerah). ${ }^{3}$

Secara umum, implementasi Pemerintahan Daerah juga disebut sebagai Otonomi Daerah dimana berdasarkan UU Pemerintahan Daerah, terdapat beberapa prinsip dasar yang harus dipegang oleh semua pihak, antara lain: pertama, Otonomi Daerah harus dilaksanakan dalam konteks negara kesatuan; kedua, Otonomi Daerah menggunakan tata cara desentralistik dimana peran Pemerintahan Daerah sangat menentukan; ketiga, pelaksanaan Otonomi Daerah harus dimulai dari mendefinisikan kewenangan, organisasi, personal dan diakhiri dengan pembahasan perimbangan keuangan, bukan sebaliknya; keempat, perimbangan keuangan yang dimaksud adalah perimbangan horizontal antar Daerah (antar Propinsi dan antar Kabupaten/Kota dalam satu Propinsi), di samping perimbangan vertikal, antar Pusat dan Daerah; kelima, fungsi Pemerintah Pusat masih sangat penting khususnya dalam kewenangan strategis (moneter, pertahanan, luar negeri, dan hukum), maupun untuk mengatasi ketimpangan antar Daerah. ${ }^{4}$

DPRD dan Kepala harusnya berperan dan berfungsi secara optimal dan bersungguh-sungguh melaksanakan setiap tahapan dalam "memperjuangkan dan mengakomodasi kepentingan rakyat", dimana Kepala Daerah tidak perlu lagi menunggu dan mendapat isyarat dari Pemerintah, begitu juga dengan DPRD yang memiliki kewenangan secara formal dalam memperjuangkan dan mengakomodasi kepentingan rakyat. Kepala Daerah harus lebih proaktif dan selalu siap melaksanakan kebijakan-kebijakan yang menyentuh aspirasi rakyat. ${ }^{5}$

DPRD dalam kedudukannya sebagai lembaga legislatif Daerah secara formal memiliki kewenangan untuk mengartikulasikan, menyalurkan, dan merumuskan berbagai aspirasi masyarakat. Lebih lanjut, Kepala Daerah menyambut aspirasi masyarakat dan mengartikulasikannya menjadi Peraturan Daerah dan atau putusan kebijaksanaan Pemerintah Daerah. Selanjutnya, segala keputusan yang telah ditetapkan Pemerintahan Daerah harus segera disosialisasikan dengan masyarakat sebagai stockholder sehingga tercipta hubungan intertrusting (saling percaya) antara masyarakat dan Pemerintahan Daerahnya sendiri.

Berdasarkan penelitian disertasi Muhammad Kamal, otonomi daerah akan berjalan dengan efektif apabila Pemerintahan Daerah dan segenap lembaga publik lainnya harus memiliki sumber daya manusia yang profesional, kapabel, dan dapat bertanggungjawab dalam menjalankan roda organisasi secara keseluruhan, sehingga Daerah menjadi lebih sensitive dalam merespon setiap percepatan kemajuan dan dinamika politik secara Nasional dan Global. Optimalisasi sumber daya manusia harus ditunjang dari pembiayaan dan pendanaan aktivitas penyelenggaraan Pemerintahan Daerah sehingga berkontribusi positif bagi peningkatan kinerja organisasi Pemerintahan Daerah secara komprehensif. Di samping itu, hal ini akan

${ }^{3}$ B., Ali Marwan H. S., and Evlyn Martha Julianthy. "Pelaksanaan Kewenangan Atribusi Pemerintahan Daerah Berdasarkan Undang-Undang Nomor 23 Tahun 2014 Tentang Pemerintahan Daerah.” Jurnal Legislasi Indonesia, Kementerian Hukum dan Hak Asasi Manusia RI 15, no. 2 (2018): hlm. 1.

${ }^{4}$ Kamal, Muhammad. "Efektifitas Penyelenggaraan Kewenangan Dalam Sistem Pemerintahan Daerah Di Sulawesi Selatan (the Effectivity of Authority Implementation of Regional Government System in South Sulawesi)." Disertasi, Universitas Hasanuddin, 2007, hlm. 7.

${ }^{5}$ Ibid., hlm. 8. 
memberikan efek penguatan terhadap sistem pemerintahan berskala nasional. ${ }^{6}$

Mohamad Yuhdi Batubara dalam penelitiannya mendeskripsikan kewenangan Pemerintahan Daerah ialah keleluasaan berprakarsa, memilih alternatif, menentukan prioritas, dan mengambil keputusan khususnya melakukan pengelolaan dan atau memperoleh dana perimbangan keuangan Pusat dan Daerah yang memadai, berlandaskan atas kriteria obyektif dan adil. Hal ini bertujuan untuk melahirkan berbagai implementasi kebijakan dan tidak lepas dari pokokpokok dan prinsip-prinsip Otonomi Daerah dalam kerangka UU Pemerintahan Daerah. $^{7}$

Lebih lanjut, pengelolaan keuangan Pemerintahan Daerah kerap menghadirkan berbagai masalah khususnya masalah pembiayaan dan anggaran daerah, atau dikenal dengan financing reform dan budgeting reform. Financing reform adalah berhubungan dengan perubahan sumber-sumber pembiayaan Pemerintahan Daerah yang meliputi perubahan sumber-sumber penerimaan keuangan daerah dan perimbangan keuangan antara Pemerintahan Daerah. ${ }^{8}$

\section{B. Rumusan Masalah}

Berdasarkan latar belakang di atas, penulis merumuskan sebuah pertanyaan atas hubungan antara DPRD dengan Kepala Daerah dalam mengelola sumber-sumber Pendapatan Asli Daerah (PAD) berdasarkan UU Pemerintahan Daerah.

\section{METODE}

Penelitian ini menggunakan metode penelitian hukum normatif yang biasa pula disebut dengan penelitian hukum doktrinal, dimana suatu penelitian hukum yang tidak menyentuh atau memasuki wilayah hukum empiris atau sosiologis untuk pengumpulan data yang dibutuhkannya. ${ }^{9}$ Penelitian hukum yang dilakukan dengan cara meneliti bahan pustaka atau data sekunder belaka, dapat dinamakan penelitian hukum normatif atau penelitian hukum kepustakaan (library legal study). ${ }^{10}$

\section{PEMBAHASAN}

\section{A. Pengelolaan Keuangan Daerah}

Selama masa Orde Baru dan seiring dengan hadirnya krisis multidimensional yang melanda bangsa Indonesia khususnya sekitaran tahun 1990an, memberikan dampak pada kemerosotan pembangunan di daerah. Hal ini dapat dilihat dari ketergantungan fiskal dan subsidi serta bantuan Pemerintah kepada Pemerintahan Daerah sebagai pertanda lemahnya Pendapatan Daerah atas Belanja Daerah. Bertolak dari kondisi tersebut membuat para aktor intelektual bangsa kemudian menggagas kembali konsep desentralisasi dan otonomi daerah dalam arti yang sebenarnya dimana indikator dari gagasan tersebut haruslah mencerminkan asas

\footnotetext{
${ }^{6}$ Ibid., hlm. 10.

${ }^{7}$ Batubara, Mohamad Yuhdi. "Eksistensi Undang Undang Nomor 32 Tahun 2004 Tentang Pemerintahan Daerah." Jurnal Ilmiah Pendidikan Pancasila dan Kewarganegaraan, Universitas Negeri Malang 25, no. 1 (2012): hlm. 25.

${ }^{8}$ Kamal, Muhammad. 2007. Op. Cit., hlm. 16.

${ }^{9}$ Qamar, Nurul, Muhammad Syarif, Dachran S. Busthami, Muhammad Kamal, Aan Aswari, Hardianto Djanggih, and Farah Syah Rezah. Metode Penelitian Hukum (Legal Research Methods). Makassar: CV. Social Politic Genius (SIGn), 2017, hlm. 49.

${ }^{10}$ Soekanto, Soerjono, and Sri Mamudji. Penelitian Hukum Normatif: Suatu Tinjauan Singkat. Jakarta: PT. Raja Grafindo Persada, 2001, hlm. 13 - 14.
} 
efisiensi, efektivitas, transparansi, akuntabilitas, dan demokratisasi nilai-nilai kerakyatan dalam praktek penyelenggaraan Pemerintahan Daerah. Gagasan ini juga memberikan perubahan paradigma yang signifikan dimana Paradigma Pembangunan Nasional bergerak menuju Paradigma Pemerataan Pembangunan secara lebih adil dan berimbang. Paradigma Pemerataan Pembangunan kemudian diwujudkan melalui satu paket Undang-Undang yaitu Undang-Undang No. 22 Tahun 1999 jo. Undang-Undang No. 32 tahun 2004 tentang Pemerintahan Daerah dan Undang-Undang No. 25 tahun 1999 jo. Undang-Undang No. 33 tahun 2004 tentang Perimbangan Keuangan Antara Pemerintah Pusat dan Daerah. Paket Undang-Undang tersebut kemudian mengalami perubahan lagi dimana melebur dalam Undang-Undang No. 23 tahun 2014 tentang Pemerintahan Daerah (UU Pemerintahan Daerah).

Keberhasilan Pemerintahan Daerah dapat dinilai dari keuangan daerah. Sehubungan dengan pentingnya posisi keuangan, efektifitas dan efisiensi dalam memberikan pelayanan dan pembangunan sebagai fungsi Otonomi Daerah akan tersendat. ${ }^{11}$ Olehnya, dalam UU Pemerintahan Daerah mengatur tentang Keuangan Daerah. Adapun penjelasan parameter dari keuangan daerah itu diatur dalam Pasal 36 Ayat (7) ${ }^{12}$ UU Pemerintahan Daerah. Untuk mencapai parameter tersebut, Pemerintahan Daerah berkewajiban untuk merealisasikan indikatorindikator dalam pengelolaan keuangan daerah sebagaimana diatur pada Pasal 280 Ayat (2) ${ }^{13}$ UU Pemerintahan Daerah. Dari penjelasan pasal tersebut, pengelolaan keuangan dan aset daerah merupakan salah satu hal yang sangat signifikan dalam mempengaruhi peningkatan PAD. Adapun penyelenggaraan Pemerintahan Daerah perihal keuangan daerah itu berasal dari dan atas beban Anggaran Pendapatan dan Belanja Daerah (APBD). Lebih lanjut, dalam Ketentuan Umum UU Pemerintahan Daerah telah menjelaskan bahwa APBD sebagai rencana keuangan tahunan dan ditetapkan melalui Peraturan Daerah (Perda). ${ }^{14}$ Adapun beberapa Pemerintahan Daerah yang berhasil mengelola keuangan daerah kurun waktu 10 tahun terakhir, antara lain: Kota Bandung, ${ }^{15}$ Kabupaten Aceh Jaya, ${ }^{16}$ dan Kabupaten Kutai Timur. ${ }^{17}$

${ }^{11}$ Delima, Nadya Ayu, Taufiq Marwa, and Anna Yulianita. "Kinerja Keuangan Daerah Terhadap Belanja Modal Untuk Pelayanan Publik Di Sumatera Bagian Selatan.” Jurnal Ekonomi Pembangunan, Universitas Sriwijaya 14, no. 2 (2016): hlm. 70.

${ }^{12}$ Pasal 36 Ayat (7) UU Pemerintahan Daerah: Parameter keuangan Daerah sebagaimana dimaksud pada Ayat (1) huruf f meliputi:

a. kapasitas pendapatan asli Daerah induk;

b. potensi pendapatan asli calon Daerah Persiapan; dan

c. pengelolaan keuangan dan aset Daerah.

${ }^{13}$ Pasal 280 Ayat (2) UU Pemerintahan Daerah: Kewajiban penyelenggara Pemerintahan Daerah dalam pengelolaan keuangan Daerah sebagaimana dimaksud pada Ayat (1) meliputi:

a. mengelola dana secara efektif, efisien, transparan dan akuntabel;

b. menyinkronkan pencapaian sasaran program Daerah dalam APBD dengan program Pemerintah Pusat; dan

c. melaporkan realisasi pendanaan Urusan Pemerintahan yang ditugaskan sebagai pelaksanaan dari Tugas Pembantuan.

${ }^{14}$ Pasal 1 (32) UU Pemerintahan Daerah: Anggaran Pendapatan dan Belanja Daerah yang selanjutnya disingkat APBD adalah rencana keuangan tahunan Daerah yang ditetapkan dengan Perda.

15Hendawati, Henda, Dekrita Komarasakti, and Surya Ansori. "Analisis Faktor-Faktor Yang Mempengaruhi Kinerja Keuangan Di Pemerintahan Daerah." Jurnal Riset Akuntansi dan Keuangan, Universitas Pendidikan Indonesia 5, no. 3 (2017): hlm. 1653.

16Sagita, Amelia Dara, Said Musnadi, and M. Shabri Abd. Majid. "Optimalisasi Pengelolaan Keuangan Berbasis Tata Kelola Pemerintahan Yang Baik Dan Dampaknya Terhadap Kinerja Pemerintahan Daerah Kabupaten Aceh Jaya.” Jurnal Magister Manajemen, Universitas Syiah Kuala 2, no. 1 (2018): hlm. 18 - 19.

${ }^{17}$ Darmanto, Aresta. "Optimalisasi Sumber Pendapatan Asli Daerah Dalam Pelaksanaan Otonomi Daerah Di Kabupaten Kutai Timur." Jurnal Administrasi Bisnis, Universitas Mulawarman 4, no. 1 (2016): hlm. 23. 
Dari penjelasan di atas, pengelolaan keuangan daerah merupakan hal yang mesti dikelola dengan baik sebagai konsekwensi dari Otonomi Daerah. Apabila Kepala Daerah tidak dapat melakukan pengelolaan keuangan daerah dengan baik, maka ciri pokok dan mendasar dari suatu Otonomi Daerah akan hilang.

\section{B. Pendapatan Asli Daerah (PAD)}

Perubahan pengelolaan keuangan daerah merupakan salah satu dampak dari Otonomi Daerah dan Desentralisasi Fiskal. Adapun perubahan pengelolaan keuangan daerah meliputi pengelolaan belanja, pembiayaan dan khususnya pendapatan daerah. Adapun sumber pendapatan daerah telah diatur dalam Pasal 285 Ayat (1) ${ }^{18}$ UU Pemerintahan Daerah. Pendapatan Asli Daerah (PAD) merupakan salah satu dari pendapatan daerah yang dimana dengan adanya aturan tersebut, Kepala Daerah dapat meningkatkan PAD guna mengurangi ketergantungan dari Pemerintah. Hal ini juga berdampak pada penguatan otonomi dan keleluasaan daerah (local discretion).

\section{Pajak Daerah}

Pajak sebagai PAD memberikan sumbangsih yang cukup signifikan bagi Pemerintahan daerah. Hal ini dibuktikan dari beberapa penelitian, antara lain Daerah Kota Langsa dimana dari tahun 2007 - 2017 penerimaan pajak daerah selalu memberikan kontribusi antara 8,2\% - 30,6\% terhadap PAD. ${ }^{19}$ Daerah Provinsi Maluku Utara dimana dari tahun 2013 - 2014 penerimaan pajak daerah memberikan kontribusi sebesar 77,57\% terhadap PAD. ${ }^{20}$ Daerah Kabupaten Badung dimana dari tahun 2011 - 2015 penerimaan pajak daerah memberikan kontribusi sebesar $88,41 \%$ terhadap PAD. ${ }^{21}$

\section{Retribusi Daerah}

Retribusi sebagai PAD memberikan sumbangsih yang cukup signifikan bagi Pemerintahan daerah. Hal ini dibuktikan dari beberapa penelitian, antara lain Daerah Kabupaten Keerom dimana dari tahun 2009 - 2013 penerimaan retribusi daerah memberikan kontribusi sebesar 25,43\% terhadap PAD. ${ }^{22}$ Daerah Kabupaten Poso dimana dari tahun 2010 - 2015 penerimaan retribusi

\footnotetext{
${ }^{18}$ Pasal 285 Ayat (1) UU Pemerintahan Daerah: Sumber pendapatan Daerah terdiri atas:

a. pendapatan asli Daerah meliputi:

1. pajak daerah;

2. retribusi daerah;

3. hasil pengelolaan kekayaan Daerah yang dipisahkan; dan

4. lain-lain pendapatan asli Daerah yang sah;

b. pendapatan transfer; dan

c. lain-lain pendapatan Daerah yang sah.

${ }^{19}$ Asnidar, Asnidar, and Chairi Syahputra. "Analisis Penerimaan Pajak Daerah Dalam Meningkatkan Pendapatan Asli Daerah Kota Langsa." Jurnal Samudra Ekonomika 2, no. 2 (2018): hlm. 156.

${ }^{20}$ Maznawaty, Elvi Syahria, Ventje Ilat, and Inggriani Elim. "Analisis Penerimaan Pajak Daerah Dalam Meningkatkan Pendapatan Asli Daerah Provinsi Maluku Utara." Jurnal EMBA, Universitas Sam Ratulangi 3, no. 3 (2015): hlm. 914.

${ }^{21}$ Taras, Tyasani, and Luh Gede Sri Artini. "Analisis Pendapatan Asli Daerah (PAD) Dalam Upaya Pelaksanaan Otonomi Daerah Di Kabupaten Badung Bali." E-Jurnal Manajemen, Universitas Udayana 6, no. 5 (2017): hlm. 2384.

${ }^{22}$ Nurlian, Siti Rofingatun, and Ivanna Wamafma. "Analisis Kontribusi Dan Potensi Retribusi Daerah (Studi Pada Dinas Pendapatan, Keuangan Dan Aset Daerah Kabupaten Keerom)." KEUDA: Jurnal Kajian Ekonomi dan Keuangan Daerah, Universitas Cenderawasih 3, no. 2 (2018): hlm. 97.
} 
daerah memberikan kontribusi sebesar $41,76 \%$ terhadap PAD. ${ }^{23}$ Daerah Provinsi Kalimantan Barat dimana dari tahun 2009 - 2014 penerimaan retribusi daerah memberikan kontribusi sebesar $112,30 \%$ terhadap PAD. ${ }^{24}$

\section{Hasil Pengelolaan Kekayaan Daerah yang Dipisahkan}

Hasil pengelolaan kekayaan Daerah yang dipisahkan (HPKDYD) sebagai PAD memberikan sumbangsih bagi Pemerintahan daerah. Hal ini dibuktikan dari beberapa penelitian, antara lain Daerah Kabupaten Poso dimana dari tahun 2010 - 2015 penerimaan HPKDYD memberikan kontribusi sebesar 3,58\% terhadap PAD. ${ }^{25}$ Daerah Provinsi Papua dimana dari tahun 2008 2014 penerimaan HPKDYD memberikan kontribusi sebesar 5,56\% terhadap PAD. ${ }^{26}$ Daerah Provinsi Bengkulu dimana dari tahun 2005 - 2008 penerimaan HPKDYD memberikan kontribusi sebesar 3,03\% terhadap PAD. ${ }^{27}$

\section{Lain-Lain PAD yang Sah}

Lain-lain PAD yang sah sebagai PAD memberikan sumbangsih bagi Pemerintahan Daerah. Hal ini dibuktikan dari beberapa penelitian, antara lain Daerah Provinsi Papua dimana dari tahun 2008 - 2014 penerimaan lain-lain PAD yang sah memberikan kontribusi sebesar $22,90 \%$ terhadap PAD. ${ }^{28}$ Daerah Provinsi Bengkulu dimana dari tahun 2005 - 2008 penerimaan lain-lain PAD yang sah memberikan kontribusi sebesar 9,24\% terhadap PAD. ${ }^{29}$

Hal terpenting yang harus dilakukan Pemerintahan Daerah perihal peningkatan PAD adalah melakukan perhitungan dengan metode yang sistematis dan rasional. PAD juga merupakan salah satu faktor yang paling penting dalam meningkatkan kapasitas fiskal daerah (fiscal capacity).

\section{Hubungan DPRD dengan Kepala Daerah dalam Mengelola Pendapatan Asli Daerah (PAD)}

Otonomi Daerah diselenggarakan oleh DPRD bersama Kepala Daerah dan dibantu oleh Perangkat Daerah yang berpedoman pada asas pemerintahan negara dan terdiri atas: ${ }^{30}$
a. kepastian hukum;
b. tertib penyelenggara negara;
c. kepentingan umum;
d. keterbukaan;
e. proporsionalitas;
f. profesionalitas;

${ }^{23}$ Maid, Abdul, Rosida P. Adam, and Yunus Sading. "Studi Kontribusi Retribusi Pada Pendapatan Asli Daerah (PAD) Kabupaten Poso Tahun 2015.” Jurnal Katalogis, Universitas Tadulako 5, no. 9 (2017): hlm. 60.

${ }^{24}$ Simangunsong, Anton. "Kontribusi Retribusi Daerah Terhadap Pendapatan Asli Daerah (Pad) Kabupaten/Kota Di Provinsi Kalimantan Barat (Periode 2009 - 2014)." JEDA: Jurnal Ekonomi Daerah, Universitas Tanjungpura 5, no. 3 (2017): hlm. 24.

${ }^{25}$ Maid, Abdul, et. al. 2017. Loc. Cit.

${ }^{26}$ Funangi, Usman, Julius Ary Mollet, and Charly M. Bisay. "Analisis Efektifitas Dan Kontribusi Hasil Pengelolaan Kekayaan Daerah Yang Dipisahkan Terhadap Pendapatan Asli Daerah (Pad) Provinsi Papua." KEUDA: Jurnal Kajian Ekonomi dan Keuangan Daerah, Universitas Cenderawasih 3, no. 2 (2018): hlm. 56.

${ }^{27}$ Baihaqi. "Analisis Kontribusi Pendapatan Asli Daerah Terhadap Pendapatan Daerah Provinsi Bengkulu." Jurnal Akuntansi, Universitas Bengkulu 1, no. 3 (2011): hlm. 263.

${ }^{28}$ Funangi, Usman, et. al. 2018. Loc. Cit.

${ }^{29}$ Baihaqi. 2011. Loc. Cit.

${ }^{30}$ Lihat Pasal 57 dan Pasal 58 UU Pemerintahan Daerah. 


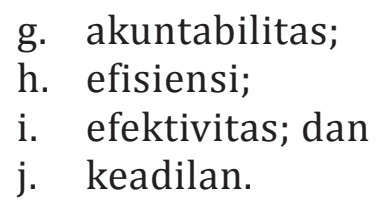

Hubungan antara DPRD dengan Kepala Daerah merupakan mitra kerja dengan kedudukan yang setara sebagaimana diatur dalam Pasal 207 Ayat (1) ${ }^{31}$ UU Pemerintahan Daerah. Salah satu bentuk dari hubungan tersebut adalah melakukan persetujuan bersama dalam pembentukan Perda. ${ }^{32}$ DPRD maupun Kepala Daerah dalam melakukan persetujuan bersama khususnya perihal APBD, keduanya memiliki kewenangan yang telah diatur dalam UU Pemerintahan Daerah.

\section{DPRD}

Pada dasarnya, baik DPRD Provinsi maupun DPRD Kabupaten/Kota memiliki ruang lingkup yang sama, perbedaannya hanya berada pada tingkat daerahnya sehingga aturan ruang lingkupnya pun ditempatkan pada Pasal yang berbeda pada UU Pemerintahan Daerah. Adapun fungsi dari DPRD meliputi: ${ }^{33}$
a. Pembentukan Perda;
b. Anggaran; dan
c. Pengawasan.

Fungsi DPRD perihal anggaran diwujudkan berdasarkan pengajuan Kepala Daerah dalam bentuk pembahasan bersama untuk menyetujui Perda dan dilaksanakan dengan cara: ${ }^{34}$
a. membahas KUA dan PPAS yang disusun oleh Kepala Daerah berdasarkan RKPD;
b. membahas rancangan Perda tentang APBD;
c. membahas rancangan Perda tentang perubahan APBD; dan
d. membahas rancangan Perda tentang Pertanggungjawaban APBD.

Fungsi DPRD perihal pengawasan lebih lanjut dijabarkan dalam bentuk: ${ }^{35}$

(1) Melaksanakan pengawasan terhadap:

a. pelaksanaan Perda dan peraturan Kepala Daerah;

b. pelaksanaan peraturan perundang-undangan lain yang terkait dengan penyelenggaraan Pemerintahan Daerah; dan

c. pelaksanaan tindak lanjut hasil pemeriksaan laporan keuangan oleh Badan Pemeriksa Keuangan (BPK).

(2) Dalam melaksanakan pengawasan sebagaimana dimaksud pada poin (1) huruf c, DPRD berhak mendapatkan laporan hasil pemeriksaan keuangan yang dilakukan oleh BPK.

(3) DPRD melakukan pembahasan terhadap laporan hasil pemeriksaan sebagaimana dimaksud pada poin (2).

(4) DPRD dapat meminta klarifikasi atas temuan laporan hasil pemeriksaan laporan keuangan kepada BPK.

\footnotetext{
${ }^{31}$ Pasal 207 Ayat (1) UU Pemerintahan Daerah: Hubungan kerja antara DPRD dan Kepala Daerah didasarkan atas kemitraan yang sejajar.

${ }^{32}$ Pasal 207 Ayat (2) huruf a UU Pemerintahan Daerah: persetujuan bersama dalam pembentukan Perda.

${ }^{33}$ Lihat Pasal 96 Ayat (1) dan Pasal 149 Ayat (1) UU Pemerintahan Daerah.

${ }^{34}$ Lihat Pasal 99 Ayat (1) dan (2) dan Pasal 152 Ayat (1) dan (2) UU Pemerintahan Daerah.

${ }^{35}$ Lihat Pasal 100 dan Pasal 153 UU Pemerintahan Daerah.
} 
Adapun tugas dan wewenang DPRD tentang APBD, antara lain yaitu: ${ }^{36}$

a. membahas dan memberikan persetujuan Rancangan Perda tentang APBD berdasarkan pengajuan Kepala Daerah;

b. melaksanakan pengawasan terhadap pelaksanaan Perda dan APBD.

\section{Kepala Daerah}

Salah satu tugas Kepala Daerah ialah menyusun dan mengajukan rancangan Perda tentang pembentukan APBD, perubahan APBD, dan pertanggungjawaban pelaksanaan APBD kepada DPRD dan dibahas secara bersama. ${ }^{37}$ Adapun kewenangan Kepala Daerah perihal APBD ialah sebagai pemegang kekuasaan terhadap pengelolaan Keuangan Daerah dan diatur dalam Pasal $284^{38}$ UU Pemerintahan Daerah.

Dari penjelasan di atas, hubungan antara DPRD dengan Kepala Daerah merupakan kemutlakan dalam menghadirkan kebijakan daerah yang berdampak pada peningkatan Pendapatan Asli Daerah (PAD). Adapun beberapa Perda yang ditetapkan berdasarkan hubungan antara DPRD dengan Kepala Daerah dan berhasil menghadirkan PAD kurun waktu 10 tahun terakhir, antara lain:

a. Perda Kota Palu No. 1 Tahun 2011 tentang Pajak Daerah, ${ }^{39}$

b. Perda Kabupaten Bangli No. 15 Tahun 2011 tentang Pajak Hotel, ${ }^{40}$

c. Perda Kota Surabaya No. 1 Tahun 2017 tentang Penerapan Sistem Online Terhadap Pajak Daerah di Kota Surabaya, ${ }^{41}$

\section{KESIMPULAN}

Kepala Daerah harus melakukan pengelolaan keuangan daerah dengan baik sebagai konsekwensi dari Otonomi Daerah dimana PAD merupakan salah satu faktor yang paling penting dalam meningkatkan kapasitas fiskal daerah. Oleh sebab itu, hubungan antara DPRD dengan Kepala Daerah merupakan kemutlakan dalam menghadirkan kebijakan daerah yang berdampak pada peningkatan Pendapatan Asli Daerah (PAD).

\footnotetext{
${ }^{36}$ Lihat Pasal 101 Ayat (1) dan Pasal 154 Ayat (1) UU Pemerintahan Daerah.

${ }^{37}$ Lihat Pasal 65 Ayat (1) UU Pemerintahan Daerah.

${ }^{38}$ Pasal 284 UU Pemerintahan Daerah:

(1) Kepala daerah adalah pemegang kekuasaan pengelolaan keuangan Daerah dan mewakili Pemerintah Daerah dalam kepemilikan kekayaan daerah yang dipisahkan.

(2) Dalam melaksanakan kekuasaan sebagaimana dimaksud pada ayat (1), kepala daerah melimpahkan sebagian atau seluruh kekuasaannya yang berupa perencanaan, pelaksanaan, penatausahaan, pelaporan dan pertanggungjawaban, serta pengawasan keuangan Daerah kepada pejabat Perangkat Daerah.

(3) Pelimpahan sebagian atau seluruh kekuasaan sebagaimana dimaksud pada ayat (2) didasarkan pada prinsip pemisahan kewenangan antara yang memerintahkan, menguji, dan yang menerima atau mengeluarkan uang.

${ }^{39}$ Massi, Rizki Rafyuman R., Muh. Faisal, and Husnah. "Analisis Penerimaan Pajak Hotel Terhadap Peningkatan Pendapatan Pajak Daerah Di Kota Palu." Jurnal Ilmu Manajemen, Universitas Tadulako 2, no. 2 (2016): hlm. 157.

${ }^{40}$ Adnyana, I Dewa Agung Yuda Tri, Putu Gede Arya Sumerthayasa, and I Ketut Suardita. "Efektivitas Peraturan Daerah Nomor 15 Tahun 2011 Tentang Pajak Hotel Di Kabupaten Bangli." Kertha Negara: Journal Ilmu Hukum, Universitas Udayana 6, no. 2 (2018): hlm. 11 - 12.

${ }^{41}$ Rawadani, Aji Rifqi, and Fidiana. "Pendapatan Asli Daerah Kota Surabaya Sebelum Dan Sesudah Sistem Pajak Online." Jurnal Ekonomi, Universitas Tarumanagara 23, no. 3 (2018): hlm. 287.
} 


\section{REFERENSI}

Adnyana, I Dewa Agung Yuda Tri, Sumerthayasa, Putu Gede Arya, \& Suardita, I Ketut. (2018). Efektivitas Peraturan Daerah Nomor 15 Tahun 2011 Tentang Pajak Hotel di Kabupaten Bangli. Kertha Negara: Journal Ilmu Hukum, Universitas Udayana, 6(2), $1-14$.

Asnidar, Asnidar, \& Syahputra, Chairi. (2018). Analisis Penerimaan Pajak Daerah dalam Meningkatkan Pendapatan Asli Daerah Kota Langsa. Jurnal Samudra Ekonomika, 2(2), $147-157$.

B., Ali Marwan H. S., \& Julianthy, Evlyn Martha. (2018). Pelaksanaan Kewenangan Atribusi Pemerintahan Daerah Berdasarkan Undang-Undang Nomor 23 Tahun 2014 Tentang Pemerintahan Daerah. Jurnal Legislasi Indonesia, Kementerian Hukum dan Hak Asasi Manusia RI, 15(2), 1 - 8.

Baihaqi. (2011). Analisis Kontribusi Pendapatan Asli Daerah Terhadap Pendapatan Daerah Provinsi Bengkulu. Jurnal Akuntansi, Universitas Bengkulu, 1(3), 246 266.

Batubara, Mohamad Yuhdi. (2012). Eksistensi Undang Undang Nomor 32 Tahun 2004 Tentang Pemerintahan Daerah. Jurnal Ilmiah Pendidikan Pancasila dan Kewarganegaraan, Universitas Negeri Malang, 25(1), 24 - 30.

Darmanto, Aresta. (2016). Optimalisasi Sumber Pendapatan Asli Daerah dalam Pelaksanaan Otonomi Daerah di Kabupaten Kutai Timur. Jurnal Administrasi Bisnis, Universitas Mulawarman, 4(1), 15 - 25.

Delima, Nadya Ayu, Marwa, Taufiq, \& Yulianita, Anna. (2016). Kinerja Keuangan Daerah Terhadap Belanja Modal untuk Pelayanan Publik di Sumatera Bagian Selatan. Jurnal Ekonomi Pembangunan, Universitas Sriwijaya, 14(2), 69 - 78.

Funangi, Usman, Mollet, Julius Ary, \& Bisay, Charly M. (2018). Analisis Efektifitas dan Kontribusi Hasil Pengelolaan Kekayaan Daerah yang Dipisahkan terhadap Pendapatan Asli Daerah (PAD) Provinsi Papua. KEUDA: Jurnal Kajian Ekonomi dan Keuangan Daerah, Universitas Cenderawasih, 3(2), 43 - 62.

Hendawati, Henda, Komarasakti, Dekrita, \& Ansori, Surya. (2017). Analisis FaktorFaktor yang Mempengaruhi Kinerja Keuangan di Pemerintahan Daerah. Jurnal Riset Akuntansi dan Keuangan, Universitas Pendidikan Indonesia, 5(3), 1643 1655.

Jalil, Husni, Husen, La Ode, Abidin, Andi, \& Rezah, Farah Syah. (2017). Hukum Pemerintahan Daerah dalam Perspektif Otonomi Khusus. Makassar: CV. Social Politic Genius (SIGn).

Kamal, Muhammad. (2007). Efektifitas Penyelenggaraan Kewenangan dalam Sistem Pemerintahan Daerah di Sulawesi Selatan (The Effectivity of Authority Implementation of Regional Government System in South Sulawesi). (Doctor Disertasi), Universitas Hasanuddin, Makassar.

Kamal, Muhammad. (2010). Efektivitas Penyelenggaraan Kewenangan dalam Sistem Pemerintahan Daerah di Indonesia. Makassar: Pustaka Refleksi. 
Kamal, Muhammad. (2011). Prinsip-Prinsip Hukum Ekonomi Islam. Al-Fikr: Jurnal Pemikiran Islam, Universitas Islam Negeri Alauddin Makassar, 15(1), 188 - 194.

Kranenburg, Roelof. (1949). Algemene Staatsleer. Haarlem: H.D. Tjeenk Willink.

Maid, Abdul, Adam, Rosida P., \& Sading, Yunus. (2017). Studi Kontribusi Retribusi Pada Pendapatan Asli Daerah (PAD) Kabupaten Poso Tahun 2015. Jurnal Katalogis, Universitas Tadulako, 5(9), 55 - 61.

Massi, Rizki Rafyuman R., Faisal, Muh., \& Husnah. (2016). Analisis Penerimaan Pajak Hotel Terhadap Peningkatan Pendapatan Pajak Daerah di Kota Palu. Jurnal IImu Manajemen, Universitas Tadulako, 2(2), 149 - 158.

Maznawaty, Elvi Syahria, Ilat, Ventje, \& Elim, Inggriani. (2015). Analisis Penerimaan Pajak Daerah dalam Meningkatkan Pendapatan Asli Daerah Provinsi Maluku Utara. Jurnal EMBA, Universitas Sam Ratulangi, 3(3), 906 - 916.

Nurlian, Rofingatun, Siti, \& Wamafma, Ivanna. (2018). Analisis Kontribusi dan Potensi Retribusi Daerah (Studi pada Dinas Pendapatan, Keuangan dan Aset Daerah Kabupaten Keerom). KEUDA: Jurnal Kajian Ekonomi dan Keuangan Daerah, Universitas Cenderawasih, 3(2), $84-100$.

Peraturan Daerah Kota Palu Nomor 1 Tahun 2011 tentang Pajak Daerah. Lembaran Daerah Kota Palu Tahun No. 1 Tahun 2011.

Peraturan Daerah Kabupaten Bangli Nomor 15 Tahun 2011 tentang Pajak Hotel. Lembaran Daerah Kabupaten Bangli No. 15 Tahun 2011.

Peraturan Daerah Kota Surabaya Nomor 1 Tahun 2017 tentang Penerapan Sistem Online Terhadap Pajak Daerah di Kota Surabaya. Lembaran Daerah Kota Surabaya No. 1 Tahun 2017.

Peraturan Pemerintah Pengganti Undang-Undang Nomor 3 Tahun 2005 tentang Perubahan atas Undang-Undang Nomor 32 Tahun 2004 tentang Pemerintahan Daerah. Lembaran Negara RI No. 38 Tahun 2005. Tambahan Lembaran Negara No. 4493.

Peraturan Pemerintah Pengganti Undang-Undang Nomor 2 Tahun 2014 tentang Perubahan atas Undang-Undang Nomor 32 Tahun 2014 tentang Pemerintahan Daerah. Lembaran Negara RI No. 246 Tahun 2014. Tambahan Lembaran Negara No. 5589.

Qamar, Nurul, Syarif, Muhammad, Busthami, Dachran S., Kamal, Muhammad, Aswari, Aan, Djanggih, Hardianto, \& Rezah, Farah Syah. (2017). Metode Penelitian Hukum (Legal Research Methods). Makassar: CV. Social Politic Genius (SIGn).

Rawadani, Aji Rifqi, \& Fidiana. (2018). Pendapatan Asli Daerah Kota Surabaya Sebelum dan Sesudah Sistem Pajak Online. Jurnal Ekonomi, Universitas Tarumanagara, 23(3), $272-289$.

Sagita, Amelia Dara, Musnadi, Said, \& Majid, M. Shabri Abd. (2018). Optimalisasi Pengelolaan Keuangan Berbasis Tata Kelola Pemerintahan yang Baik dan Dampaknya terhadap Kinerja Pemerintahan Daerah Kabupaten Aceh Jaya. Jurnal Magister Manajemen, Universitas Syiah Kuala, 2(1), 11 - 21. 
Simangunsong, Anton. (2017). Kontribusi Retribusi Daerah Terhadap Pendapatan Asli Daerah (PAD) Kabupaten/Kota di Provinsi Kalimantan Barat (Periode 2009 2014). JEDA: Jurnal Ekonomi Daerah, Universitas Tanjungpura, 5(3), 1 - 31.

Soekanto, Soerjono, \& Mamudji, Sri. (2001). Penelitian Hukum Normatif: Suatu Tinjauan Singkat. Jakarta: PT. Raja Grafindo Persada.

Taras, Tyasani, \& Artini, Luh Gede Sri. (2017). Analisis Pendapatan Asli Daerah (PAD) dalam Upaya Pelaksanaan Otonomi Daerah di Kabupaten Badung Bali. E-Jurnal Manajemen, Universitas Udayana, 6(5), 2360 - 2387.

Undang-Undang Nomor 22 Tahun 1999 tentang Pemerintahan Daerah. Lembaran Negara RI No. 60 Tahun 1999. Tambahan Lembaran Negara No. 3839.

Undang-Undang Nomor 25 Tahun 1999 tentang Perimbangan Keuangan antara Pemerintah Pusat dan Daerah. Lembaran Negara RI No. 72 Tahun 1999. Tambahan Lembaran Negara No. 3848.

Undang-Undang Nomor 32 Tahun 2004 tentang Pemerintahan Daerah. Lembaran Negara RI No. 125 Tahun 2004. Tambahan Lembaran Negara No. 4437.

Undang-Undang Nomor 33 Tahun 2004 tentang Perimbangan Keuangan antara Pemerintah Pusat dan Pemerintahan Daerah. Lembaran Negara RI No. 126 Tahun 2004. Tambahan Lembaran Negara No. 4438.

Undang-Undang Nomor 12 Tahun 2008 tentang Perubahan Kedua atas Undang-Undang Nomor 32 Tahun 2004 tentang Pemerintahan Daerah. Lembaran Negara RI No. 59 Tahun 2008. Tambahan Lembaran Negara No. 4844.

Undang-Undang Nomor 23 Tahun 2014 tentang Pemerintahan Daerah. Lembaran Negara RI No. 244 Tahun 2014. Tambahan Lembaran Negara No. 5587.

Undang-Undang Nomor 9 Tahun 2015 tentang Perubahan Kedua atas Undang-Undang Nomor 23 Tahun 2014 tentang Pemerintahan Daerah. Lembaran Negara RI No. 58 Tahun 2015. Tambahan Lembaran Negara No. 5679. 